\title{
MAGYARORSZÁG JÁRÁSI SZINTÜ TURISZTIKAI CENTRUMTÉRSÉGEINEK LEHATÁROLÁSA ÉS HAZÁNK KIEMELT TURISZTIKAI TÉRSÉGEIVEL TÖRTÉNŐ ÖSSZEVETÉSE TÉRÖKONOMETRIAI MÓDSZEREKKEL
}

\author{
Végi Szabina \\ Pécsi Tudományegyetem, Közgazdaságtudományi Kar, Regionális Politika és Gazdaságtan \\ Doktori Iskola,PhD hallgató; mikeine.vegi.szabina@ktk.pte.hu
}

DOI: 10.15170/TVT.2021.06.03.03.

\begin{abstract}
Absztrakt
A gazdaság más területeihez hasonlóan a turizmusban is felfedezhetők centrumok és perifériák, melyek létrejötte részben - de mindenképp meghatározó mértékben - a keresletet is kiváltó turisztikai vonzerők eltérő előfordulásával, területi megjelenésével, koncentrációjával, illetve dekoncentrációjával magyarázható. Magyarország különböző területi szinteket érintő turisztikai térségeinek lehatárolása tekintetében több kísérlet is történt, azonban az egységes szempontrendszer és módszertan hiánya mindig problematikussá tették a kapott eredmények gyakorlati életbe történő hatékony átültetését. A legutóbbi, kiemelt turisztikai fejlesztési térségek desztinációs logika mentén történő beazonosítása és lehatárolása 2016-ban kezdődött, melynek révén figyelembe vették egyrészt a keresleti és a kínálati tényezőket, másrészt pedig a térségekben rejlő turisztikai potenciált. Ennek eredményeként 2020 szeptemberében jelent meg a turisztikai térségekről szóló legújabb kormányrendelet, amely 11 új turisztikai térség létrejöttéröl döntött, kiegészítve ezzel a korábbi kiemelt fejlesztési térségeket. Jelen tanulmány keretein belül, egyfajta módszertani kísérletként, a turisztikai teljesítményt alapul véve térökonometriai módszerek segítségével járási szinten próbáljuk lehatárolni Magyarország turisztikai térségeit, $\mathrm{s}$ a kapott eredményeinket összevetni a lehatárolt 11 turisztikai térséggel, megvizsgálva ezek egyezéseit, esetleges eltéréseit. A kutatás egyik fö célkitüzése annak igazolása, vagy elvetése, hogy a térökonometria alkalmas eszköz lehet-e a turisztikai térségek lehatárolásában.
\end{abstract}

Kulcsszavak: turisztikai centrumtérségek, kiemelt turisztikai térségek, térinformatika, térökonometria 


\begin{abstract}
As in other fields of economy, centers and peripheries can be noticed in the case of tourism as well, which can be explained partly - but to a significant extent - by the different occurrences, territorial appearances, concentrations and deconcentrations of tourist attractions. Several attempts have been made to subdivide the tourism regions of Hungary, but the lack of an unified system of criterias and methodologies has always made the implementation of the results problematic. The most recent identification and delimitation of accentuated tourism development areas along a destination logic started in 2016, taking into account both supply and demand factors and the tourism potential of the areas. As a result, the latest government decree on tourist areas was published in September 2020, deciding on the creation of 11 new tourist areas, supplementing the previous priority development areas. Within the framework of the present study, as a kind of methodological experiment as well, based on the tourism performance, we try to subdivide the tourist regions of Hungary at the district level with the help of spatial econometric methods, and compare our results with the previously mentioned 11 tourist regions. We try to examine their matches and possible differences. One of the main results of the research is to prove or disprove whether spatial econometrics can be a suitable tool in the delineation of tourist areas.
\end{abstract}

Keywords: touristic central areas, accentuated tourism regions, geoinformatics, spatial econometric 


\section{Bevezetés}

A turizmus az elmúlt évtizedek egyik legdinamikusabban fejlődő szektora, munkahelyteremtő hatása mellett a gazdasági növekedés egyik legfontosabb motorja is egyben (HALL 2004, MICHALKÓ 2010). A turizmus a magyar gazdaságban is igen jelentős helyet foglal el, a bruttó hazai termékhez hozzáadott értéke évről évre - természetesen az ismert okok miatt 2020-at leszámítva - rekordokat dönt (CSAPÓ - LŐRINCZ 2020). A KSH szatellit számla adatai alapján a turizmus gazdasághoz való közvetlen hozzájárulása a GDP 6,8\%-a, a közvetett hatásokat is magában foglaló hozzájárulás pedig a GDP 10,7\%-a. 2019-ben a vendégek száma a kereskedelmi szálláshelyeken elérte a 12,8 milliót, míg a vendégéjszakák száma meghaladta a 31,2 milliót. A kereskedelmi szálláshelyek szállásdíj-bevétele 9,2 százalékkal, a szálláshelyi összbevétel 8,8 százalékkal nőtt 2018-hoz viszonyítva (KSH 2019).

Magyarországot egyebek mellett természetesen területi és települési szintü különbségek jellemzik, mely úgy a társadalmi, gazdasági szférában, mint a lakosság életkörülményeiben is megmutatkozik. Az ország jellegzetesen egypólusú, fővárosa az egyetlen olyan hazai település, ahol a növekedési tényezők kritikus tömege rendelkezésre áll (VARGA - LENGYEL 2019). Még ha túlzás is az országot egyetlen régiónak tekinteni, melynek centruma maga a fóváros, $\mathrm{s}$ minden más a perifériát alkotja, a fóváros - vidék dualizmus kétségkívül a területi egyenlőtlenség egyik meghatározó szintje Magyarország esetében (NEMES NAGY 1990, BELUSZKY 2014, KÁPOSZTA-GUBACSI 2018). A turizmusban szintén felfedezhetők centrumok és perifériák, amelyek részben a turisztikai vonzerők eltérő előfordulásával magyarázhatók (AUBERT-SZABÓ 2007, MARTON et al. 2016).

Jelen tanulmány keretein belül a turisztikai teljesítményt alapul véve térökonometriai módszerek segítségével próbáljuk lehatárolni Magyarország azon turisztikai térségeit, ahol a turizmus járási szintủ és a járások közötti koncentrációját tapasztalhatjuk, s a kapott eredményeinket összevetni az újonnan lehatárolt 11 turisztikai térséggel, megvizsgálva ezek területi egyezéseit, esetleges eltéréseit. A turisztikai térségek térbeli lehatárolása a stratégiai célkitüzések megalapozása szempontjából is kulcsfontosságú kérdés, mely indokolja tanulmányunk létjogosultságát. A tanulmány egyik fő célja a módszertan relevanciájának és alkalmazhatóságának bizonyítása. A térökonometria az ökonometria azon részterülete, mely a keresztmetszeti és paneladatokra épülő regressziós modellekben a térbeli interakció és a térbeli struktúra által generált ökonometriai problémák kezelésével foglalkozik (VARGA 2002).

A tanulmány elsősorban szemlélet- és módszertanbeli sajátosságok bemutatására vállalkozik melynek során elöször ismertetjük a 2020 szeptemberében lehatárolt 11 turisztikai térséget. Ezt követi az elemzés során használt adatok ismertetése, majd az empirikus modell, amit az alkalmazott térökonometriai módszerek bemutatása követ. Ezt követően értelmezzük a kapott eredményeket, végül összefoglaljuk a tanulmány legfontosabb megállapításait.

\section{Magyarország kiemelt turisztikai térségeinek lehatárolása - a Magyar Turisztikai Ügynökség legújabb megközelítésének bemutatása}

A kiemelt turisztikai fejlesztési térségek desztinációs logika mentén történő beazonosítása és lehatárolása 2016-ban kezdődött, figyelembe véve mind a keresletet és a kínálatot, mind pedig a térségekben rejlö további turisztikai lehetőségeket. 2020 szeptemberétől a Nemzeti Turizmusfejlesztési Stratégia 2030 által korábban megnevezett öt kiemelt turisztikai fejlesztési térséget 11 újonnan lehatárolt turisztikai térség váltott fel (1. ábra).

A korábbi fejlesztésközpontú szemlélet helyét a marketing és az értékesítési fókusz vette át. A lehatárolás során fontos szempont volt az is, hogy egymástól jól megkülönböztethető, s már rövidtávon versenyképes desztinációkat hozzanak létre (NTS 2030). 


\section{1. ábra. Magyarország 11 turisztikai térsége.}

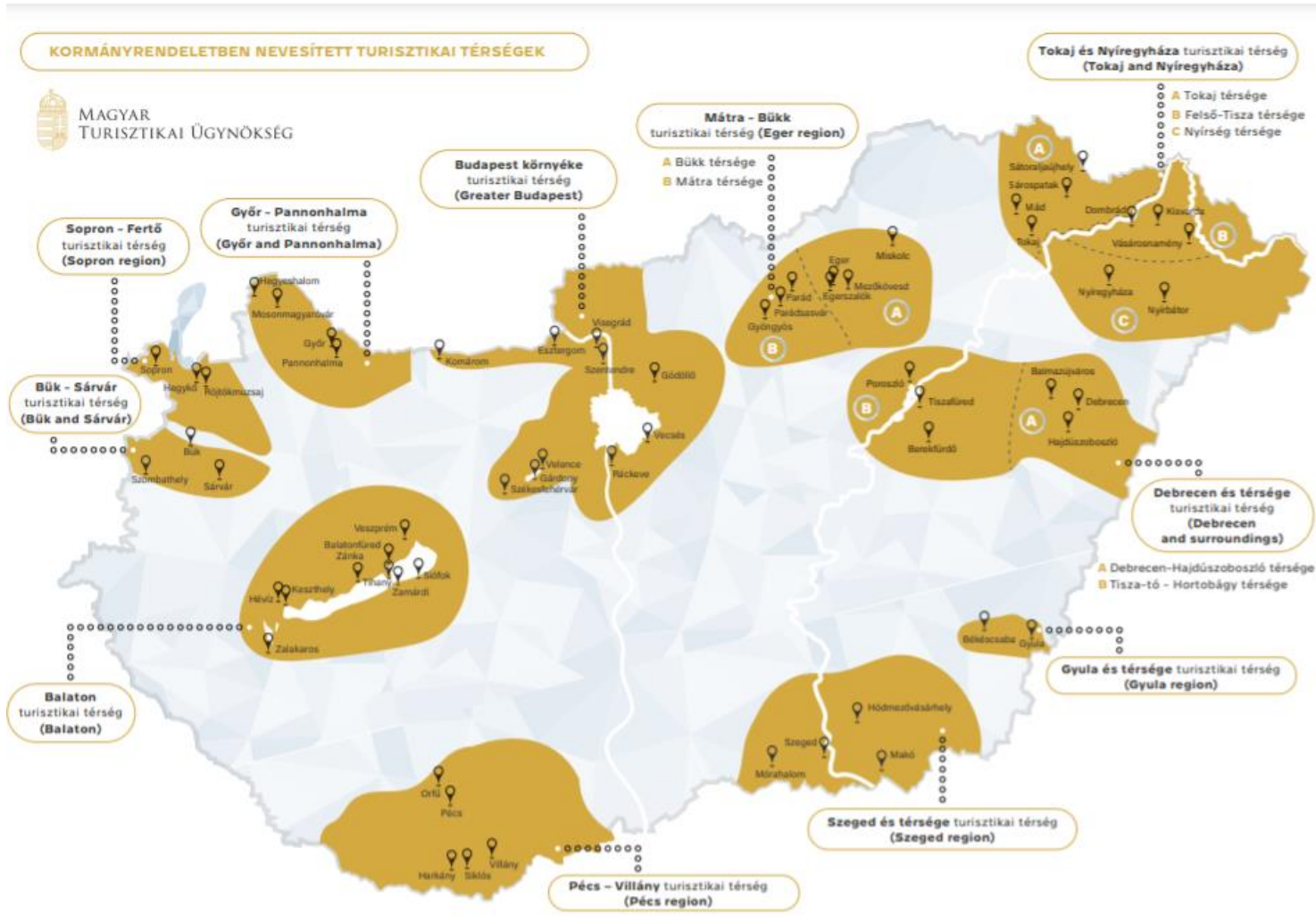

Forrás: https://mtu.gov.hu/cikkek/11-turisztikai-terseg-terkep-es-telepuleslista-1918

\section{Az adatok és az empirikus modell bemutatása}

\section{$2.1 \mathrm{Az}$ adatok ismertetése}

Kutatásunk során a KSH által gyüjtött és nyilvánosan hozzáférhető adatokkal dolgoztunk. Mivel település szinten adatvédelmi okokból sok helység neve mellett szerepelt volna nullás adat, mely jelentősen torzított, értelmezhetetlen eredményekre vezetett volna, a megyei szint pedig egyszerre túl nagy területi egységet fedett volna le a megfigyeléseinkhez, így ezen okokból kifolyólag a kutatásunk során járási szintü adatokkal dolgoztunk.

A felhasznált adatok a 2019. évre vonatkoznak. Az előzetes vizsgálatokba mind a 197 járás, ebböl 23 fővárosi kerület, került bevonásra. Végül azokat a járásokat ${ }^{8}$, ahol valamely, lentebb részletezett, változóhoz tartozó szám nulla volt, a torzítás elkerülése végett, nem vontuk be a vizsgálatba, így végül egy 175 elemü mintához jutottunk.

Az 1. táblázat tartalmazza az elemzésünk során használt változók leírását.

\footnotetext{
${ }^{8}$ Bácsalmási, Cigándi, Csengeri, Derecskei, Encsi, Gyáli, Hajdúhadházi, Ibrányi, Jánoshalmai, Mezőcsáti, Nagykállói, Sárbogárdi, Sarkadi, Sellyei, Szentlőrinci, Szikszói, Téti, Várpalotai, Záhonyi, XVII. kerületi, XXI. kerületi, XXII. kerületi járások
} 
1. táblázat: A változók leírása.

\begin{tabular}{|l|l|}
\hline Jelölés & Leírás/Mértékegység \\
\hline VENDEGEJ_2019 & Összes vendégéjszakák száma 2019-ben, járási szinten \\
\hline OSSZES_KER_2019 & $\begin{array}{l}\text { Kereskedelmi szálláshely szállásférőhelyeinek száma 2019- } \\
\text { ben, járási szinten }\end{array}$ \\
\hline KULFOLDI_2019 & $\begin{array}{l}\text { Külföldi vendégek száma a kereskedelmi szálláshelyeken } \\
\text { 2019-ben, járási szinten }\end{array}$ \\
\hline GYOGYHELY_DUMMY & $\begin{array}{l}\text { Gyógyhely dummy változó. Amennyiben található } \\
\text { gyógyhely az adott járásban a Budapest Fóváros } \\
\text { Kormányhivatalának országos nyilvántartása szerint úgy az } \\
\text { érték 1, amennyiben nem található úgy az érték 0. }\end{array}$ \\
\hline
\end{tabular}

Forrás: Saját szerkesztés

A modellépítés során sokféle változóval ${ }^{9}$ dolgoztunk, a végleges modellbe viszont kizárólag statisztikailag szignifikáns és egzakt módon mérhető magyarázóváltozók kerültek bevonásra. Mely eredményünket a következő szakmai érvek is alátámasztják:

\section{1. Összes vendégéjszakák száma 2019-ben, járási szinten:}

A téma újszerüsége miatt a szakirodalom nem bővelkedik a kutatásunkhoz kapcsolódó tanulmányokban, ezért a turisztikai teljesítményt az alapmüveknek számító munkákban foglaltak szerint a turisztikai kereslet legfontosabb indikátorának számító vendégéjszakák számával mérjük (MICHALKÓ 2016, OLIVERI et al. 2013, HALL 2004, LENGYEL 2004), s elemzésünkben ez lesz az eredményváltozó.

\section{Kereskedelmi szálláshelyek féröhelyeinek száma 2019-ben, járási szinten:}

Korábbi kutatások bizonyították, hogy a turisztikai teljesítményt befolyásoló tényezők között közvetlen hatást mutatott a turisztikai potenciálként általánosított szállásféröhelyszám (OLAH et al. 2017, KÓRÓDI et al, 2011), ezért ez lett a modellünk egyik magyarázóváltozója.

\section{Gyógyhely dummy változó:}

Napjainkban újra reneszánszát éli a fürdőkultúra. A korábban trendinek mondott egészségtudatosság valódi trenddé vált, s a fogyasztók már nemcsak gyógyulás, hanem egészségmegörzés, rekreáció céljából is felkeresnek egészségközpontokat, wellness- és gyógyszállókat (JÓNÁS-BERKI et al 2015, CSAPÓ et al. 2011, GONDA 2016). A gyógyturizmus, mint trend népszerüsége egyértelmüen pozitív hatással van a gyógyhellyel ${ }^{10}$ rendelkező desztinációk turisztikai teljesítményére, amit mi sem bizonyít jobban, mint az a

\footnotetext{
9 Vendégek száma a kereskedelmi szálláshelyeken, vendégéjszakák száma a kereskedelmi szálláshelyeken, belföldi vendégek száma a kereskedelmi szálláshelyeken, belföldi vendégéjszakák száma a kereskedelmi szálláshelyeken, vendégek átlagos tartózkodási ideje (éjszaka), külföldi vendégek száma a kereskedelmi szálláshelyeken, külföldi vendégéjszakák száma a kereskedelmi szálláshelyeken, vándorlási egyenleg (ezrelék), lakónépesség, regisztrált munkanélküliek száma összesen, tartós munkanélküliek aránya, foglalkoztatást helyettesítő támogatás egy főre jutó havi átlagos összege, összes kereskedelmi szálláshely szállásférőhelyeinek száma ezer lakosra, regisztrált gazdasági vállalkozások száma ezer lakosra.

${ }^{10}$ A gyógyhely megnevezés nem azonos a gyógyvíz vagy gyógyfürdő megnevezéssel, használata az Állami Népegészségügyi és Tisztiorvosi Szolgálat Országos Tisztifőorvosi Hivatala által kiadott engedélyhez kötött. A Hivatal vizsgálja, hogy van-e az adott helyen olyan elismert természetes gyógytényező, mint például a gyógyvíz, gyógyiszap, gyógygáz vagy az éghajlat. Az is fontos, hogy ezek igénybevételéhez rendelkezésre álljanak a megfelelö intézmények, ami lehet gyógyfürdő, gyógyszálló, gyógybarlang, mofetta.
} 
tény, hogy 2019-ben a TOP 10 legnépszerübb úti cél közül (a budapesti kerületeket nem számítva) 7 rendelkezett gyógyhellyel (KSH 2020, MARTON 2019, CSAPÓ 2017). Fenti indokok mentén tehát dummy változóként a gyógyhelyek jelenlétét választottuk.

\section{Külföldi vendégek száma:}

A hazánk településeire látogató határon túlról érkező turisták általában hosszabb időt töltenek el, mint a belföldiek, több szolgáltatást vesznek igénybe és magasabb a költési hajlandóságuk is (KSH 2007), ami szintén pozitív irányba mozdítja el az adott desztináció turisztikai teljesítményét. Emellett a külföldi turisták jelenléte a fürdöhelyeknél további koncentrációt mutat, amit megfelelően bizonyít, hogy a 175 elemü mintánkból 33 járásban található gyógyhely, ebből 28-ban magasabb volt a külföldiek által eltöltött átlagos tartózkodási idő, mint a belföldiek esetében (kivétel: Dombóvári, Gyulai, Hajdúnánási, Miskolci, Mórahalmi járások).

\subsection{Az empirikus modell bemutatása}

A fent ismertetett változók tükrében az empirikus modellünk a következőképpen alakul:

Összes vendégéjszakák száma $=\beta 0+\beta 1 \times$ összes kereskedelmi szálláshely szállásférőhelyeinek száma $+\beta 2 \times$ külföldi vendégek száma a kereskedelmi szálláshelyeken + $\beta 3 \times$ gyógyhely dummy változó $+\mathrm{u}$.

A modellünk alapján tehát a turizmus teljesítményének kiemelt elemei/meghatározói a kereskedelmi szálláshelyek férőhelyeinek a száma, illetve az ott megforduló külföldi vendégek száma és az, hogy az adott járásban található-e gyógyhely.

A továbbiakban azt teszteljük, hogy a turisztikai teljesítmény mutatójának tekintetében megfigyelhetö-e területi autokorreláció. A következőkben röviden bemutatjuk a tanulmányban alkalmazott térökonometriai módszereket, elsősorban ANSELIN-REY (2014), valamint VARGA (2002) munkáira támaszkodva.

\section{A magyarországi járások turisztikai teljesítményének mérése és területi viszonyainak bemutatása térökönometriai módszerrel}

A 2. ábra azt mutatja, hogy az adott területi egység értéke mennyire tér el a teljes adatsor átlagától. A térökonometriai elemzést a GeoDa térökonometriai szoftverrel hajtottuk végre, az adatállomány 197 járási területi szintre vonatkozóan tartalmaz adatokat. Ez alapján 6 darab olyan turisztikai csomópontot tudunk megnevezni, melyek az országos átlag felett teljesítenek, név szerint a következők: Keszthelyi, Balatonfüredi, Siófoki, Hajdúszoboszlói, Egri járások és a föváros belső kerületei. 


\section{2. ábra. A magyarországi járások turisztikai teljesítményének átlagtól való eltérése az összes vendégéjszaka tekintetében}

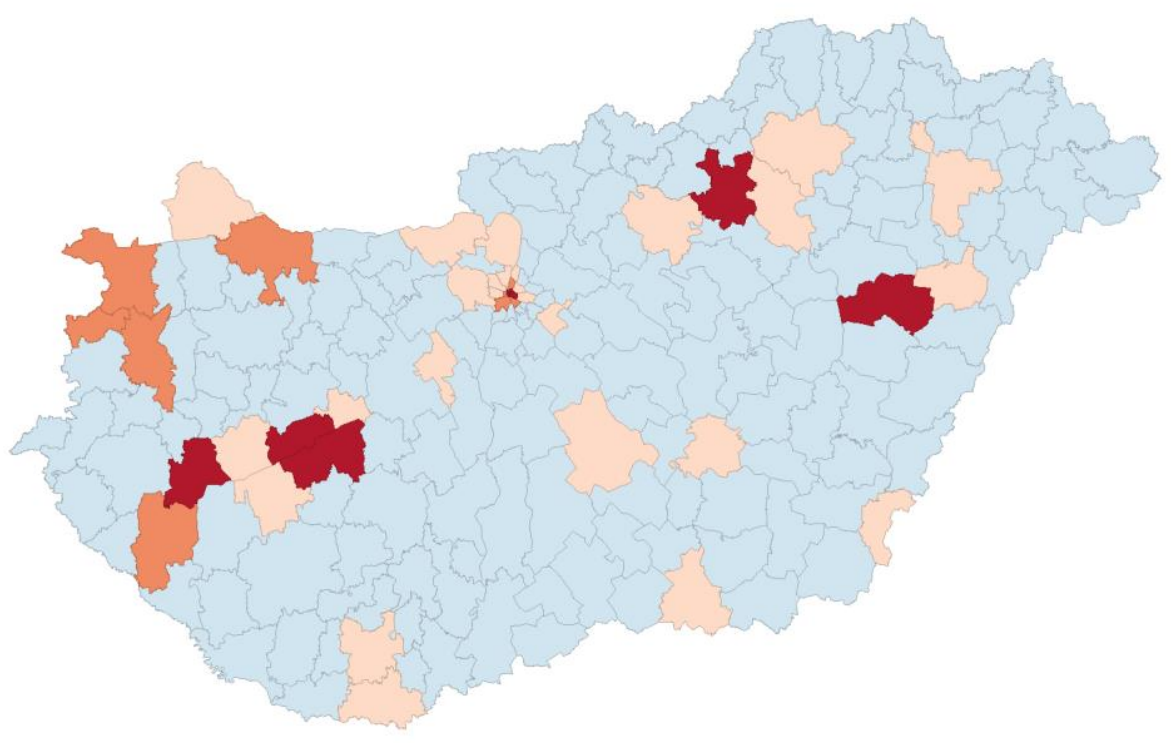

Forrás: Saját szerkesztés

Ezeken felül pedig összesen 13 turisztikai térség rajzolódik ki a turisztikai teljesítmény mutató, vagyis az összes vendégéjszakák száma tekintetében:

1. Balaton és környéke

2. Budapest és környéke

3. Pécsi és Siklósi járások

4. Sopron, Köszegi és Sárvári járások

5. Mosonmagyaróvár és Győri járások

6. Gárdonyi járás

7. Kecskeméti járás

8. Kunszentmártoni járás

9. Szegedi járás

10. Gyulai járás

11. Hajdúszoboszlói és Debreceni járások

12. Nyíregyházi járás

13. Gyöngyösi, Egri, Mezőkövesdi és Miskolci járások

Amikor a térbeli függőség jelenlétét szeretnénk tesztelni, célszerü először megvizsgálni, hogy tapasztalható-e az eredményváltozónkban térbeli autokorreláció. A térbeli autokorrelációt a Moran-féle I-statisztikával mérhetjük. Autokorreláció hiányában a szomszédos járások értékei függetlenek egymástól, időben nem hatnak egymásra, és a járások távolsága nem befolyásolja a turisztikai teljesítményben mutatkozó különbségeket. Erős pozitív területi autokorrelációról 
beszélhetünk, ha a területi különbségekre jelentősen hatnak a szomszédsági viszonyok, tehát minél közelebb vannak a járások egymáshoz, annál inkább hasonló a turisztikai teljesítményünk (VARGA 2010).

A vizsgálatunkhoz három különböző térbeli súlymátrixot használtunk:

1. Királynő szomszédsági mátrix, amikor két terület szomszédos, ha közös határaik vannak.

2. Inverz távolságalapú súlymátrix, amikor a növekvő távolsággal csökken a területi egységek közötti korreláció.

3. A k legközelebbi szomszéd mátrix.

2. táblázat. A vendégéjszakák számának Moran-féle I-értéke különböző térbeli súlymátrixok esetén

\begin{tabular}{|c|c|c|c|}
\hline & $\begin{array}{c}\text { Királynő } \\
\text { szomszédsági mátrix }\end{array}$ & $\begin{array}{c}\text { Inverz távolságalapú } \\
\text { súlymátrix }\end{array}$ & $\begin{array}{c}\text { A k legközelebbi } \\
\text { szomszéd mátrix }\end{array}$ \\
\hline Moran I & 0,407 & $-0,029$ & $-0,008$ \\
\hline permutációk száma & 999 & 999 & 999 \\
\hline pseudo p-érték & 0,001 & 0,304 & 0,493 \\
\hline z core & 10,028 & $-0,578$ & $-0,136$ \\
\hline
\end{tabular}

Forrás: Saját szerkesztés

A királynő szomszédsági mátrix mellett legnagyobb az I-érték, tehát ez ragadja meg legjobban a térbeli függőség szerkezetét. A Moran-féle I-statisztika értéke 0,407, ami közepesnél valamivel gyengébb mértékủ pozitív térbeli autokorrelációra utal a turisztikai teljesítmény tekintetében. A szignifikancia tesztelésekor 999 véletlen permutáció 0,001-es pseudo p-értéket eredményezett, ami alapján a térbeli autokorreláció minden konfidencia szinten szignifikánsnak tekinthető. Tehát ezek alapján elmondhatjuk, hogy nem véletlen, hogy ilyen mértékü koncentrálódás tapasztalható a járások turisztikai teljesítményét illetően.

\section{3. ábra. A magyarországi járások turisztikai teljesítményén alapuló klasztertérképe.}

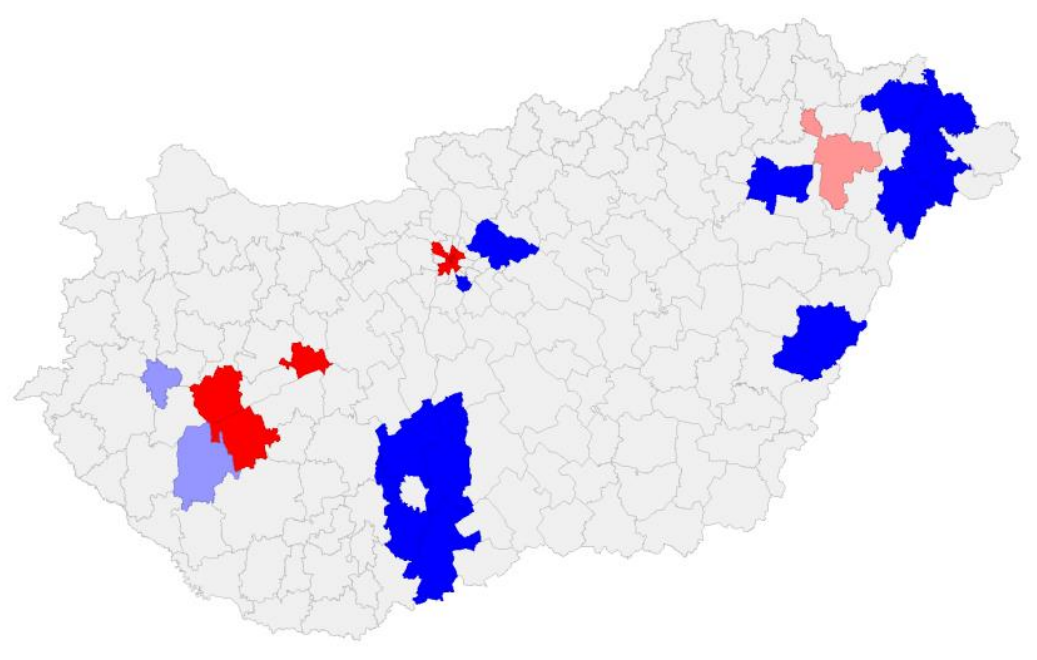

Forrás: Saját szerkesztés 
A 3. ábra azt mutatja, hogy a következő járások és azok szomszédjai is kiemelkedő turisztikai teljesítménnyel bírnak: Fonyódi, Tapolcai járások, illetve a főváros belső kerületei.

Ezek alapján elmondható, hogy erős klaszteresedés figyelhető meg a kiemelkedő turisztikai teljesítménnyel rendelkező járások tekintetében a Balaton környékén, míg az alacsony turisztikai teljesítménnyel bíró járások tekintetében a Duna partján fekvő Paksi, Bajai, Szekszárdi és Kalocsai járásoknál, illetve az Észak-Alföldön.

\section{4. ábra. A magyarországi járások turisztikai teljesítményén alapuló szignifikanciatérképe.}

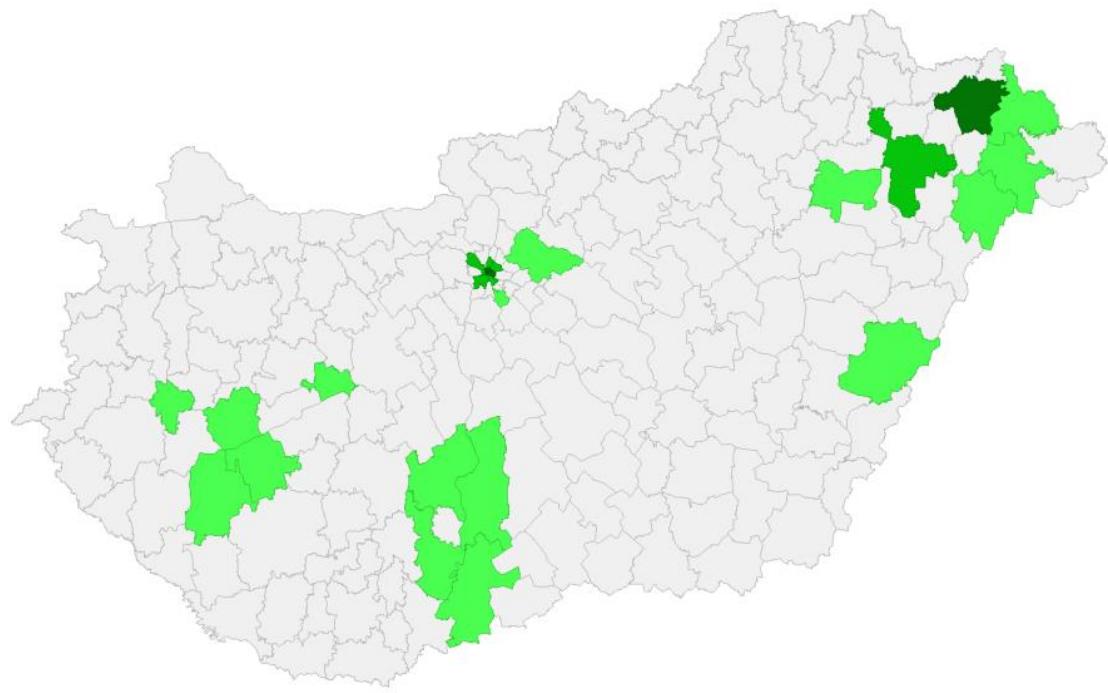

Forrás: Saját szerkesztés

A szignifikanciatérképen a sötétzölddel kiemelt járások térbeli autokorrelációja $0,1 \%$-os szignifikancia szint mellett, míg a világosabb zöld színü járások $1 \%$ és $5 \%$-os szignifikancia szint mellett mutatnak szignifikáns kapcsolatot. Bár a térbeli autokorreláció elemzése hasznos kiindulópontja egy térökonometriai vizsgálatnak, a fentiek alapján nem tudjuk, hogy vajon mi okozza a hasonló értékek térbeli klaszteresedését. Emiatt ajánlott regressziós modell keretei között vizsgálni, hogy a változóban tapasztalható-e térbeli függőség.

Regressziós elemzés

A regressziós modellt a klasszikus legkisebb négyzetek módszerével (OLS) becsültük. A tér struktúrájának meghatározásához a fentebb részletezett, három különböző súlymátrixot használtunk. 
3. táblázat. Térbeli modell OLS becslésének eredményei.

\begin{tabular}{|c|c|c|c|c|}
\hline $\begin{array}{l}\text { Eredményváltozó: } \\
\text { VENDEGEJ_2019 }\end{array}$ & Koefficiensek & Standard hiba & $\begin{array}{l}\mathrm{t} \\
\text { érték }\end{array}$ & p-érték \\
\hline Konstans & $-5297,59$ & 8439,45 & $-0,62$ & 0,53 \\
\hline OSSZES_KER_2019 & 40,66 & 2,15 & 18,84 & $<0,001$ \\
\hline GYOGYHELY_DUMMY & 138166,86 & 18416,35 & 7,50 & $<0,001$ \\
\hline KULFOLDI_2019 & 2,21 & 0,07 & 29,01 & $<0,001$ \\
\hline Megfigyelések száma & 175 & & & \\
\hline Globális F próba & $<0,001$ & & & \\
\hline $\mathrm{R}^{2}$ & 0,9247 & & & \\
\hline Korrigál $\mathrm{R}^{2}$ & 0,9234 & & & \\
\hline
\end{tabular}

\begin{tabular}{|l|l|l|}
\hline Multikollinearitás mutató & 2,231 & \\
\hline Jarque-Bera & 3761,175 & 0,0000 \\
\hline Breusch-Pagan teszt & 639,153 & 0,0000 \\
\hline Lagrange Multiplier (lag) & 0,058 & 0,8093 \\
\hline Robust LM (lag) & 0,000 & 0,9909 \\
\hline Lagrange Multiplier (error) & 0,345 & 0,5572 \\
\hline Robust LM (error) & 0,286 & 0,5925 \\
\hline
\end{tabular}

Forrás: Saját szerkesztés

A globális $\mathrm{F}$ próba alapján a modell létezik $(\mathrm{p}<0,001)$. A kapott eredmények alapján a modell 92,4\%-ban magyarázza a függő változó varianciáját $\left(\mathrm{R}^{2}=0,924\right)$, ami nagyon erős magyarázó erőnek mondható. Az összes vendégéjszakák száma tehát így írható fel $=-5297+138166$ (gyógyhely dummy változó) + 2,21 (külföldi vendégek száma) + 40,66 (összes kereskedelmi szálláshely szállásférőhelyeinek száma, ezer lakosra). A modellt értelmezve megállapítható, hogy amennyiben található gyógyhely az adott járásban az 138166-al növeli éves szinten az összes vendégéjszakák számát ceteris paribus. Ha egységnyivel növeljük a külföldi vendégek számát, az 2,21-el növeli az összes vendégéjszakák számát, míg, ha egységnyivel nő az összes kereskedelmi szálláshely szállásférőhelyeinek száma, az 40,66-al növeli az összes vendégéjszakák számát ceteris paribus. Multikollinearitás problémánk nincs. A Jarque- Berapróba alapján 1 százalékos szignifikanciaszinten elvetjük a hibatag normális eloszlásának nullhipotézisét, míg a Breusch-Pagan-próba alapján, szintén 1 százalékos szignifikanciaszinten a hibatag homoszkedaszticitásának nullhipotézisét. Az $\mathrm{LM}_{\mathrm{lag}}$ és az $\mathrm{LM}_{\text {error-próba eredményei, }}$ illetve a robusztus tesztstatisztikák alapján sem tudjuk elvetni a térbeli függetlenség nullhipotézisét egyik térbeli súlymátrix esetén sem, így térbeli függőséget nem tudunk megállapítani az adott modellünkkel. A heteroszkedaszticitást a White-féle becsléssel kezeltük, melynek következtében megváltoztak a koefficiensek standard hibái. 
4. táblázat. Eredményeink a White-féle becslést követően.

\begin{tabular}{|c|c|c|c|c|}
\hline $\begin{array}{l}\text { Eredményváltozó: } \\
\text { VENDEGEJ_2019 }\end{array}$ & Koefficiensek & Standard hiba & $\begin{array}{l}\mathrm{t} \\
\text { érték }\end{array}$ & p-érték \\
\hline Konstans & $-5297,59$ & 8889,09 & $-0,59$ & 0,55 \\
\hline OSSZES_KER_2019 & 40,66 & 9,01 & 4,51 & $<0,001$ \\
\hline GYOGYHELY_DUMMY & 138166,86 & 34026,02 & 4,06 & $<0,001$ \\
\hline KULFOLDI_2019 & 2,21 & 0,11 & 19,58 & $<0,001$ \\
\hline Megfigyelések száma & 175 & & & \\
\hline Globális F próba & $<0,001$ & & & \\
\hline $\mathrm{R}^{2}$ & 0,9247 & & & \\
\hline Korrigál $\mathrm{R}^{2}$ & 0,9234 & & & \\
\hline
\end{tabular}

\begin{tabular}{|l|l|l|}
\hline Multikollinearitás mutató & 2,231 & \\
\hline Jarque-Bera & 3761,175 & 0,0000 \\
\hline Breusch-Pagan teszt & 639,153 & 0,0000 \\
\hline Lagrange Multiplier (lag) & 0,058 & 0,8093 \\
\hline Robust LM (lag) & 0,000 & 0,9909 \\
\hline Lagrange Multiplier (error) & 0,345 & 0,5572 \\
\hline Robust LM (error) & 0,286 & 0,5925 \\
\hline
\end{tabular}

Forrás: Saját szerkesztés

Jelen modellel nem sikerült a térbeli függőséget megállapítani, ezért különböző térbeli rezsimeket hoztunk létre a turisztikai teljesítmény alapján. A térbeli rezsimek a térbeli heterogenitás egyik formája, amely strukturális különbségeket jelent a térben.

1. Balaton és Budapest környéke

2. A kiemelt turisztikai teljesítménnyel bíró nyugat-dunántúli járások, Balaton és Budapest környéke

3. A kiemelt turisztikai teljesítménnyel bíró nyugat-dunántúli, észak-magyarországi és északalföldi járások, Balaton és Budapest környéke

Egyik esetben sem sikerült térbeli függőséget megállapítanunk, melynek oka véleményünk szerint az, hogy a turisztikai teljesítmény bármennyire is a turisztikai szolgáltatóktól függőnek tünik, nem szabad megfeledkeznünk olyan helyi tényezők fontosságáról, mint a fekvés, a hagyományok, a hírnév vagy a vendégfogadási hajlandóság, melyek igen színes képet mutatnak országos viszonylatban, s nagy részük a természeti adottságoktól függ. 


\section{A kiemelt turisztikai térségek és az általunk lehatárolt járási szintü területi turisztikai térségek lehetséges területi egyezéseinek kérdései}

A turizmus országon belüli helyzetét nagyban meghatározzák a természeti adottságok, melyek változatosságot és sokszínűséget mutatnak országszerte. Véleményünk szerint mind a kiemelkedő, mind az alacsony turisztikai teljesítménnyel rendelkező járások koncentráltsága ezzel hozhatók összefüggésbe, mintsem a szomszédos járások turisztikai teljesítményével.

Bár a turizmus kialakulásában számos tényező játszik szerepet, az egyik legmeghatározóbb az ember alkotta attrakciók mellett a természet adta lehetőségek. Fontos megjegyezni, hogy bár a természeti tényezők minden változásuk ellenére is bizonyos állandóságot, stabilitást képviselnek, ami értelemszerüen vonatkozik a turizmusra is, ennek ellenére a természeti alapú turisztikai desztináció tartósságának, stabilitásának előnye nem automatikusan jön létre. Ezért is fontos ezen térségek pontos lehatárolása és célzott fejlesztése.

Bár térökonometriai szempontból térbeli függőséget nem sikerült kimutatnunk, az előzetes vizsgálatok során a magyarországi járások turisztikai teljesítményének tekintetében mégis sikerült 13 térséget lehatárolnunk, melyeket az 5 . ábrán vetettünk össze a kormányrendeletben lehatárolt 11 magyarországi turisztikai térséggel.

Ez alapján 3 csoportot tudtunk felállítani.

1. Az első csoportba kerültek azok a járások, ahol átfedéseket találtunk a lehatárolások szempontjából. Ezt a csoportot kiemelkedő turisztikai teljesítménnyel bíró térségeknek neveztük el, s négyzetráccsal jelöltük.

2. A második csoportba azok a járások kerültek, amelyeket a térökonometria módszerével nem, de a kormányrendeletben foglaltak szerint lehatárolásra kerülnek. Ezeket potenciális, fejlesztendő turisztikai térségeknek neveztük el és pöttyökkel jelöltük.

3. A harmadik csoportba azok a járások kerültek, melyek turisztikai teljesítménye jobb az átlagnál, de a kormányrendelt mégsem nevezte meg őket a 11 turisztikai térség közt, ezeket átlós vonalakkal jelöltük.

A 11 turisztikai térség desztinációfejlesztési stratégiájára, imázsára, arculatára, márkájának kialakítására, piaci pozíciójának meghatározására 4 milliárd forintot különítettek el, ezért azok a térségek, melyek turisztikai teljesítménye országos viszonylatban az átlagtól magasabb, de mégsem kerültek be a kormányrendelet által kijelölt 11 térségbe, egyértelmüen vesztesnek érezhetik magukat. Vizsgálatunk során két ilyen járást találtunk, az egyik a kecskeméti, a másik pedig a kunszentmártoni, ami Cserkeszőlő gyógyhatású termálfürdőjének köszönhetően került fel Magyarország turisztikai térképére, s egyre nagyobb népszerüségnek örvend az elmúlt 5-10 évben.

Érdekes még kiemelni a Budapest környéki járásokat, melyek támogatottsága mögött azt az elképzelést véljük meghúzódni, ami még a koronavírus-járvány kitörését megelőzően próbálta Budapest vonzáskörzetét bevonni a turizmusba, ezzel enyhítve a főváros belső kerületein, felkapott helyein lévő nyomást. Szintén érdemes megemlíteni az észak-magyarországi és az észak-alföldi régió határmenti járásait, melyek turisztikai teljesítménye az ökonometriai elemzés alapján kifejezetten alacsonynak mondható a kormányrendelet mégis kiemelten kezeli azokat, mint versenyképes turisztikai régiókat. 


\section{5. ábra. Magyarország járási szintű turisztikai térségei és az MTÜ által lehatárolt 11 turisztikai térség közti átfedés kimutatása.}

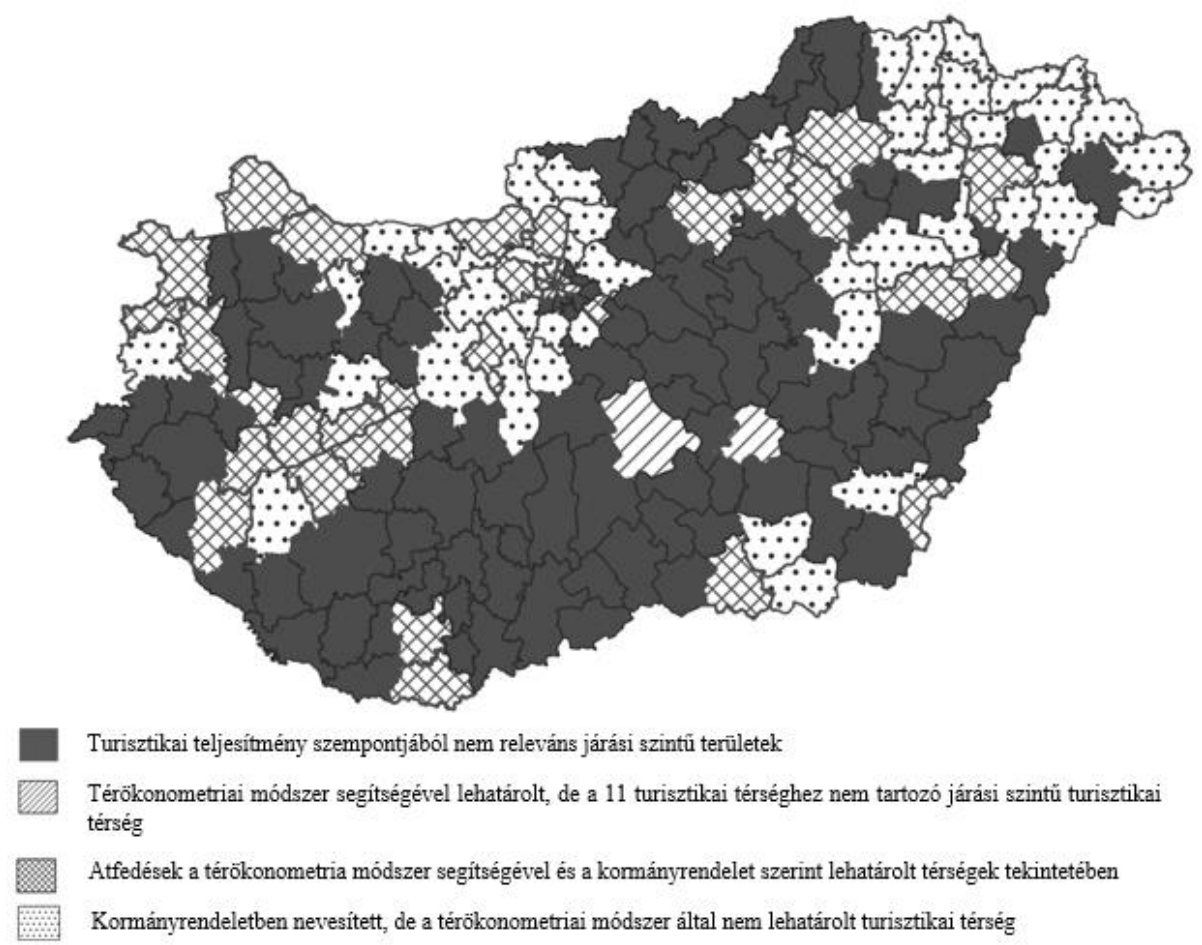

Forrás: saját szerkesztés

\section{Összefoglalás}

Jelen tanulmány keretein belül a turisztikai teljesítményt alapul véve térökonometriai módszerek segítségével járási szinten próbáltuk lehatárolni Magyarország turisztikai térségeit, s a kapott eredményeinket összevetni a lehatárolt 11 turisztikai térséggel, megvizsgálva ezek egyezéseit, esetleges eltéréseit. A turisztikai teljesítmény mutatójának tekintetében igen alacsony mértékü területi autokorreláció figyeltünk meg, mely magyarázatát a természeti adottságokban, mintsem a szomszédos járások turisztikai teljesítményében láttuk. Bármennyire is a turisztikai szolgáltatóktól függőnek tünik a turizmus teljesítményének alakulása, a vendégéjszakák számának változása, nem feledkezhetünk meg a helyi tényezők fontosságáról, amelyek a térségi szintek rangsorában lefelé haladva egyre jelentősebbé válnak. A tanulmány egyik fö limitációja, hogy adatvédelmi okokból kifolyólag a KSH által rendelkezésünkre bocsátott települési szintü adatok jelentősen torzított, értelmezhetetlen eredményekre vezettek volna, így kutatásunk során járási szintủ adatokkal dolgoztunk. Úgy véljük azonban, hogy a szemlélet- és módszertanbeli sajátosságok bemutatására ezen területi szint is alkalmasnak bizonyult, így a turisztikai kutatások centrum-periféria kutatásainak módszertanát jelen megközelítés reményeink szerint tovább tudta gazdagítani.

\section{Irodalomjegyzék}

ANSELIN, L. - REY, S. J. (2014): Modern Spatial Econometrics in Practice: A Guide to GeoDa, GeoDa Space and PySAL . GeoDa Press.

AUBERT, A. - SZABÓ, G. (2007): A Dél-dunántúli régió turisztikai magterületeinek lehatárolása. Xellum Kft. Budapest, pp. 1-23. 
BELUSZKY, P. (2014): Budapest - zászlóshajó vagy vízfej?, Tér és Társadalom 32. évf., 1. szám

BRÓDY, A. (2005): A multiplikátor és története, Közgazdasági Szemle, LII. évf., 2005. április (402-416. o.)

CUNHA, D. S. K. - DA CUNHA, D. J. C. (2005): Tourism Cluster Competitiveness and Sustainability: Proposal for a Systemic Model to Measure the Impact of Tourism on Local Development, BAR, v. 2, n. 2, art. 4, pp. 47-62.

CSAPÓ, J. - MARTON, G. (2011): The Role of Health Tourism in the Hungarian Small and Medium Sized Towns In: Jiř́, Ježek; Lukáš, Kaňka (szerk.) Competitiveness and Sustainable Development of the small Towns and Rural Regions in Europe Plzen, Csehország: University of West Bohemia, pp. 29-39. , 12 p.

CSAPÓ, J. - MARTON, G. (2017): The Role and Importance of Spa and Wellness Tourism in Hungary’s Tourism Industry, Czech Journal of Tourism, 6: 1 pp. 55-68. , 14 p.

CSAPÓ, J. (2019): A turizmuspolitika és turizmusirányitás elmélete és gyakorlata az Európai Unióba, Akadémiai Kiadó

CSAPÓ, J. - GONDA, T. (2019): A hazai lakosság utazási motivációinak és szokásainak elemzése az aktív turizmus és a fizikai aktivitás tekintetében. In: Turisztikai és Vidékfejlesztési Tanulmányok, 4(4), pp. 57-70.

CSAPÓ, J. - LŐRINCZ, K. (2020): A turizmus gazdaságban betöltött szerepe és irányai Magyarországon a Covid-19 előtt és után, GeoMetodika 4. 3. pp. 5-16.

CSORDÁS, L. (2019): Koncentráció és térbeli terjedés az 1990 utáni hazai turizmusban a kereskedelmi szálláshelyek kapacitása és forgalma alapján, Gradus Vol 6, No 3. pp. 88-101.

GONDA, T. (2016): A turisztikai termékfejlesztés elméleti alapjai, PTE KPVK Szekszárd, ISBN 9789634291084

GONDA, T. - NAGY, D. - RAFFAY, Z. (2019): The impact of tourism on the quality of life and happiness. Interdisciplinary Management Research/Interdisziplinare Managementforschung 15, pp. 1790-1803.

HALL, C. M. (2004): Spatial analysis: A critical tool for tourism geographies. - In: Wilson, J. (szerk.): The Routledge handbook of tourism geographies. Routledge, London. pp. 163-173.

JÓNÁS-BERKI, M. - CSAPÓ, J. - PÁLFI, A. - AUBERT, A. (2015): A Market and Spatial Perspective of Health Tourism Destinations: The Hungarian Experience International Journal of Tourism Research $17: 6$ pp. 602-612., 11 p.

KÁPOSZTA, J. - GUBACSI, F. (2018): Kedvezőtlen helyzetü települések napjainkban Bátonyterenye példáján keresztül, Studia Mundi - Economica Vol. 5. No. 3.

KÓRÓDI, M. (2006): A vidéki turizmusfejlesztés összefüggései a magyarországi kistérségekben, Doktori (PhD) értekezés, Szent István Egyetem Gödöllő

KÓRÓDI, M. (szerk.) (2011): Turizmus kutatások módszertana, Pécsi Tudományegyetem, Kempelen Farkas Hallgatói Információs Központ. ISBN: 978-963-642-431-2

LENGYEL, M. (2004): A turizmus általános elmélete, Heller Farkas Gazdasági és Turisztikai Szolgáltatások Főiskolája, pp. 525 
MARTON, G. - RAFFAY, Z. - PRISZTÓKA, GY. - RAFFAY, Á. - KISS, R. (2016): A Dráva-mente, mint határmenti, periférikus tér turizmusfejlesztésének problémái, Turisztikai és Vidékfejlesztési Tanulmányok 2677-0431 2498-6984 12 34-48

MARTON, G. - HINEK, M. - KISS, R. - CSAPÓ, J. (2019): Measuring seasonality at the major spa towns of Hungary, Hungarian Geographical Bulletin (2009-) 68 : 4 pp. 391-403. , $13 \mathrm{p}$.

MICHALKÓ, G. (2010): Boldogitó utazás: a turizmus és az életminőség kapcsolatának magyarországi vonatkozásai. - MTA Földrajztudományi Kutatóintézet, Budapest. pp. 119.

MICHALKÓ, G. (2016): Turizmológia - Elméleti alapok, Akadémiai Kiadó, Budapest, 2012. 266 o.

NEMES NAGY, J. (1990): Területi kiegyenlítődés és differenciálódás Magyarországon, Földrajzi Értesitő XXXIX. év f. 1990.1-4. füzet, pp. 151-173.

OLIVERI, A. - CANTIS, S. D. (2013): Analysing Local Tourism, McGraw-Hill Education Europe, pp. 350

VARGA, A. (2002): Térökonometria. Statisztikai Szemle, 80. évf. 4. sz. 354-370. o.

VARGA, A. - LENGYEL, I. (2019): Földrajz és gazdasági növekedés Magyarországon továbblépés és újabb diagnózisok, Közgazdasági Szemle 66. évf. 6. sz.

VÁRY, M. (2017): Számít-e a földrajzi elhelyezkedés? A nyugat-európai régiók fejlettségének térökonometriai vizsgálata, Közgazdasági Szemle, LXIV. évf., 2017. március pp. 238-266.

VÉGI, SZ. - CSAPÓ, J. - TÖRÖCSIK, M. (2020): Az új koronavírus (COVID-19) megjelenésének hatása a magyar lakosság turisztikai fogyasztói szokásaira - egy online felmérés elsödleges eredményei, in Ercsey Ida (szerk.): Marketing a digitalizáció korában. Széchenyi István Egyetem: Győr. ISBN: 978-615-5837- pp. 357-368.

\section{Egyéb források:}

http://www.ksh.hu/docs/hun/xftp/stattukor/regiok/gyorgyogyturizmus06.pdf (utolsó letöltés: 2021. 01. 10.)

https://www.ksh.hu/docs/hun/xstadat/xstadat_eves/i_oga002.html (utolsó letöltés: 2021. 01. 12.)

https://www.ksh.hu/docs/hun/xstadat/xstadat_eves/i_oga016.html (utolsó letöltés: 2021. 01. 12.)

https://www.ksh.hu/docs/hun/xstadat/xstadat_eves/i_ogt009.html (utolsó letöltés: 2021. 01. 12.)

https://www.ksh.hu/docs/hun/xstadat/xstadat_eves/i_oga002.html (utolsó letöltés: 2021. 01. 12.)

http://www.ksh.hu/docs/hun/xftp/idoszaki/jeltur/2019/index.html (utolsó letöltés: 2021. 02. 04.)

https://mtu.gov.hu/cikkek/11-turisztikai-terseg-terkep-es-telepuleslista-1918 (utolsó letöltés: 2021. 02. 04.)

https://net.jogtar.hu/jogszabaly?docid=a1600156.tv (utolsó letöltés: 2021. 02. 05.) 